\title{
António de Sousa Teles de Menezes: um caso singular de ascensão social na Capitania de Goiás
}

\section{António de Sousa Teles de Menezes: a singular case of social ascension in the Goiás Capitania}

\author{
Luís Alberto Mendonça*
}

\begin{abstract}
Resumo
As sociedades do Antigo Regime, ainda que herdeiras da sociedade "trinitária" medieval, conheceram uma situação de maior mobilidade social. Tal situação esteve bem presente nos espaços coloniais portugueses, nomeadamente no Brasil, nos quais se abriram amplas perspetivas de ascensão social, proporcionadas por novas oportunidades de enriquecimento, pelo exercício de cargos considerados nobilitantes e, por vezes, pela política de mercês da Coroa. No presente artigo, o nosso propósito foi o de reconstituir a trajetória social de António de Sousa Teles de Menezes na capitania de Goiás, uma região mineradora e periférica do Brasil colonial, realçando a forma como ele se movimentou na sociedade da época e identificando as estratégias a que recorreu para reforçar a seu estatuto social, de forma a tornar viável uma situação de ascensão social que o conduzisse à nobilitação.
\end{abstract}

Palavras-chave: António Menezes; Goiás; mobilidade social; nobilitação.

\begin{abstract}
Abstrat
The Old Regime societies, despite being heirs of the "trinitarian" medieval society, have experienced a situation of greater social mobility. This situation was very present in Portuguese colonial spaces, especially in Brazil, where broad prospects of social promotion were opened, favored by new opportunities for enrichment, by the exercise of positions considered noble, and sometimes by the Crown's mercy policy. In this article, our purpose was to reconstitute António de Sousa Teles de Menezes's social trajectory in the captaincy of Goias, a mining and peripheral region of colonial Brazil, highlighting the way he progressed in the society of his time and identifying the strategies that he used to strengthen his social status, in order to allow him the social ascension that would lead him to nobilitation.
\end{abstract}

Keywords: António Menezes; Goiás; social mobility; nobilitation.

*Mestre em Letras pela Universidade de Lisboa. E-mail: luismendonca.cno@gmail.com 


\section{Considerações iniciais}

É cada vez mais consensual que a micro e a macro-história não se encontram em terrenos antagónicos, mas complementares, e que as abordagens metodológicas quantitativas e qualitativas não se opõem, antes se completam. ${ }^{1}$

Isto após um período em que, como observou Jacques Revel, o programa da micro-história foi encarado com desconfiança e, até, com ceticismo pela historiografia dominante, das longas durações, dos tempos longos, dos espaços amplos e das estruturas. ${ }^{2} \mathrm{E}$ já Guy Lardreau chamava a atenção para a ilusão perigosa que prevalecia nos anos setenta e oitenta de considerar a história quantitativa como a única que merecia um estatuto científico, ao passo que a história qualitativa, pelo menos implicitamente, era vista de forma depreciativa. ${ }^{3}$

Ainda que essas desconfianças se mantenham em alguns círculos historiográficos mais fiéis à chamada história estrutural, ${ }^{4}$ tem-se assistido a uma crescente valorização das histórias de vida, das biografias, da reconstituição das trajetórias individuais, até porque esses percursos individuais estão perfeitamente conectados com o todo social. Parte-se do pressuposto de que, se o todo social, o tempo e os contextos históricos condicionam o percurso dos indivíduos, também um conhecimento mais exaustivo das partes (dos indivíduos e as suas trajetórias) conduz a uma melhor compreensão do todo (da sociedade em geral). E, como sublinhou José Cardozo, "já que a macro-história permite a construção de generalizações e a micro-história enfoca o sujeito, por que não unir as duas abordagens para melhor compreensão da História?". ${ }^{5}$

Na mesma linha de pensamento se situa José Mattoso, quando realça as virtualidades das biografias, desde que não se limitem a reconstituir o

\footnotetext{
${ }^{1} \mathrm{Cf}$. LALANDA, Piedade, "Sobre a metodologia qualitativa na pesquisa sociológica”, in Análise Social, Lisboa, Instituto de Ciências Sociais da Universidade de Lisboa, 1998, vol. XXXIII (148), (4º), p. 872;

${ }^{2}$ Cf. REVEL, Jacques, "Micro-história, macro-história: o que as variações de escala ajudam a pensar em um mundo globalizado", in Revista Brasileira de Educação, Rio de Janeiro, 2010, v. 15 n. 45, set, p. 434 e seguintes [online, acesso a 28 de março de 2016, URL:http://www.scielo.br/pdf/rbedu/v15n45/03.pdf.].

${ }^{3}$ Cf. DUDY, Georges \& LARDEAU, Guy, Diálogos sobre Nova Historia, Lisboa, Publicações Dom Quixote, 1989, p. 96.

${ }^{4}$ A história estrutural, que teve em Fernand Braudel o seu representante máximo, sobrevalorizava as estruturas, aquilo que permanecia imutável por longos períodos de tempo, ao passo que o tempo curto, os acontecimentos e o papel dos indivíduos eram relegados para um plano bastante secundário enquanto elementos explicativos do processo histórico.

${ }^{5}$ CARDOSO, José Carlos da Silva, "Reflexões sobre a abordagem macro e micro na História", in MNEME, Revista de Humanidades, Publicação do Departamento de História da Faculdade Federal do Rio Grande do Norte, Ago/Dez 2010, 11 (28), p. 31. [online, acesso a 22 de abril de 2016, URL:http://www.periodicos.ufrn. $\mathrm{br} / \mathrm{mneme} /$ article/viewFile/1045/992].
} 
percurso individual do protagonista, mas se preocupem em percecionar o modo como ele é influenciado e exprime a sua época, ou de que forma nele se refletem as estruturas e os movimentos globais. O que interessa é a relação que o indivíduo estabelece com o conjunto em que se insere e do qual ele se torna um interlocutor privilegiado. Assim, "por meio dele, o conjunto aparece, então, sob a sua forma histórica, situado no tempo e no espaço e objectivado em indivíduos concretos. Ultrapassam-se as abstracções". ${ }^{6}$

Da mesma forma, para Jacques Revel, a micro-história passou a ser vista como uma nova modalidade de análise social,

própria de uma que almejasse atentar para a experiência dos indivíduos captada nas relações que eles mantêm com outros indivíduos. A escolha do individual não era considerada, no caso, contraditória com a apreensão do social: o que se esperava dela era que se tornasse possível a inclusão de uma trajetória individual (a de um homem ou de um grupo de homens) numa multiplicidade de espaços e de tempos sociais, pelo novelo de relações sociais que se criam em volta dessa trajetória e dão-lhe sua significação.?

Partindo desse contexto, começam a ser frequentes os estudos historiográficos que procuram percecionar e reconstituir as trajetórias individuais, nomeadamente ascensionais, no espaço colonial brasileiro. Carla Almeida sublinha, a propósito, que nas últimas décadas a historiografia brasileira sobre o período colonial tem deslocado as suas atenções das análises estruturais para a valorização do papel dos indivíduos como definidores do rumo dos processos históricos. ${ }^{8}$ A título de exemplo, Roberta Stumpf reconstituiu de forma rigorosa as trajetórias nobilitantes dos chamados "cavaleiros do ouro" em Minas Gerais, ou seja, daqueles que obtiveram o hábito de Cavaleiros de Cristo, fruto da sua ligação à mineração. ${ }^{9}$

\footnotetext{
${ }^{6}$ MATTOSO, José, A Escrita da História, teoria e métodos, Lisboa, Editorial Estampa, 1988, p. 60.

${ }^{7}$ REVEL, Jacques, op. cit., pp. 438-439.

${ }^{8}$ ALMEIDA, Carla, "Vivendo à lei da nobreza nas Minas Setecentistas: uma discussão sobre o estatuto social na América Portuguesa", in Anais do II Encontro Memorial do Instituto de Ciências Humanas e Sociais/ UFOP. Ouro Preto: UFOP, 2009.

${ }^{9}$ STUMPF, Roberta G., Cavaleiros do ouro e outras trajectórias nobilitantes: as solicitações de Hábitos das Ordens Militares nas Minas Setecentistas, tese de Doutoramento, Universidade de Brasília, 2009. Podemos ainda mencionar outros estudos: NAUK, Maria de Jesus, "As pessoas Principais da terra: os oficiais das câmaras da fronteira oeste da América portuguesa", in Congresso Internacional Pequena Nobreza nos Impérios Ibéricos do Antigo Regime, Lisboa, 18 a 21 de maio de 2011, pp. 1-10 [online, acesso a 28 de set. de 2014, URL: http://www. iict.pt/pequenanobreza/arquivo/Doc/t2s1-01.pdf]; MELLO, Marcia Eliane Alves de Souza e, "Perspectivas sobre a 'nobreza da terra' na Amazônia Colonial”, in Revista de História, São Paulo, jan/junho de 2013, nº 168, pp 26-68 [online, acesso a 7 de abril de 2015, URL: http://www.revistas.usp.br/revhistoria/article/ viewFile/59143/62172].
} 
Posto isto, o estudo que aqui apresentamos, o da reconstituição da trajetória de António de Sousa Teles de Menezes, procura, essencialmente, realçar a forma como ele se movimentou na sociedade da época, uma sociedade do Antigo Regime, mais precisamente no espaço colonial brasileiro, e identificar as estratégias a que recorreu para reforçar a sua situação social, o seu estatuto, ou as opções por ele tomadas num universo limitado de possibilidades. Com efeito, enquadrando-se nos valores do Antigo Regime e consciente da sua condição de partida, fora do universo dos grupos privilegiados, António de Menezes procurou explorar todas as possibilidades que a sociedade lhe disponibilizava para ir consolidando o seu estatuto e tornar viável uma situação de ascensão social que o conduzisse à nobilitação.

$\mathrm{Na}$ forma hábil como soube aproveitar as estratégias de que dispunha para concretizar os seus objetivos de promoção social residiu, sem dúvida, um dos grandes méritos de António Teles de Menezes, tornando-o um caso singular de sucesso na capitania de Goiás, um espaço periférico do Brasil colonial. ${ }^{10} \mathrm{~A}$ singularidade do seu percurso de vida residiu, igualmente, no facto de ele ter assumido uma posição crítica que roçava os limites da ousadia face a determinadas práticas e comportamentos mais ou menos institucionalizados, ainda que dignos de reprovação à luz dos valores da época. São estes aspetos que constituem precisamente o objeto da nossa atenção.

\section{O percurso ascensional de António de Sousa Teles de Menezes}

António de Sousa Teles de Menezes seria natural de Porto. ${ }^{11}$

Embora oriundo de uma família inserida no grupo bastante heterogéneo do Terceiro Estado, o pai e os avós possuíam terras próprias, eram lavradores. ${ }^{12}$

\footnotetext{
${ }^{10}$ Parte do território de Goiás situava-se a ocidente do meridiano definido pelo Tratado de Tordesilhas (área espanhola). Numa aceção mais simbólica, o caráter fronteiriço de Goiás poderá entender-se, igualmente, no sentido de uma "capitania em processo de ocupação", com uma linha de demarcação mais ou menos fluída entre o espaço civilizado pelos colonizadores, do ainda ocupado pelos indígenas, não submetido e caracterizado pelo caos e ausência de civilização. JULIO, Suelen, "Relações em espaços fronteiriços: indígenas e sociedade envolvente na capitania de Goiás", in XVI Encontro Regional de História, Anpuh - Rio de Janeiro, 28 de julho a 1 de agosto de 2014, pp. 1-10, [online, acesso a 16 de julho de 2015, URL http://www. encontro2014.rj.anpuh.org/resources/anais/28/1399239817_ARQUIVO_Anpuh14.pdf].

${ }^{11}$ Noutras fontes António Teles de Menezes surge como sendo natural de Vila Fria, Guimarães. Cf. BERTRAN, Paulo (org.) Notícia Geral da capitania de Goiás em 1783, Goiânia-Brasília, Editora da Universidade Católica de Goiás-Editora da Universidade Federal de Goiás-Solo Editores, 1997, tomo II, p. 47.

${ }^{12}$ ANTT, HOC, Letra A, Maço 32, doc. 1. Segundo Carlos Manuel Lopes, existia uma clara diferença entre lavradores, que controlavam a exploração da terra, normalmente na qualidade de proprietários, e uma diversidade de trabalhadores agrícolas (caseiros, jornaleiros, etc.), o que correspondia a diferentes estatutos a nível social e económico. LOPES, Carlos Manuel Faísca Bruno, "Desigualdades de rendimento no Alentejo do Antigo Regime: Arraiolos, Avis e Portalegre (1690-1725)", Análise Social, Lisboa, ICS, 215, 1 (2.ํ), 2015.
} 
Por conseguinte, seriam detentores de alguns recursos económicos, situação que terá permitido a António Teles de Menezes frequentar a Universidade de Coimbra, da qual saiu com o título de bacharel em leis em 1755. Esta foi, sem dúvida, a sua primeira grande conquista, a de integrar o grupo dos letrados, um grupo de elite no seio do Terceiro Estado, ${ }^{13}$ uma situação que lhe seria muito útil para outras conquistas posteriores. Depois de formado, atravessou o Atlântico em direção ao Rio de Janeiro, ficando alojado em casa do tio, Pantaleão de Sousa Teles. Tendo permanecido aí uns escassos seis meses, exercendo advocacia, ${ }^{14}$ partiu para um novo desafio, rumou a Vila Boa de Goiás, onde continuou a dedicar-se à profissão de advogado. ${ }^{15}$

Que razões teria António Teles de Menezes para trocar a cidade do Rio de Janeiro pela capitania de Goiás? Que vantagens poderia ele vislumbrar na longínqua Vila Boa de Goiás que não encontrava na movimentada e estrategicamente localizada cidade do Rio de Janeiro? o que o movia a trocar o centro pela periferia do Brasil colonial?

As fontes a que tivemos acesso não se pronunciam sobre esta questão. Mas, certamente, ele terá percecionado que em Goiás teria mais amplas oportunidades de atingir uma situação de notoriedade social. Para começar, numa capitania em que as instâncias judiciais ainda estariam numa fase muito incipiente, em que as demandas e as querelas eram frequentes, a desordem e o desrespeito pela lei eram situações banais, ${ }^{16}$ António Teles de Menezes encontraria aí o terreno ideal para testar as suas qualidades como advogado. Mais, numa região em que o analfabetismo imperava, António Teles de Menezes, com a sua formação académica, teria múltiplas oportunidades para ocupar variados cargos ao serviço da res publica, que iriam ao encontro dos seus propósitos de promoção social e, até, de nobilitação. Por fim, sendo Goiás uma das mais importantes regiões de mineração do Brasil colonial, residia aqui mais

\footnotetext{
${ }^{13}$ Os historiadores são unânimes em reconhecer que os letrados e os comerciantes de grosso trato se posicionavam nos lugares cimeiros do Terceiro Estado, ocupando frequentemente cargos municipais e perfilando-se como os principais candidatos para uma possível ascensão social que os conduziria à nobilitação. Segundo José Damião Rodrigues, o grupo dos letrados e, em particular, o dos advogados, já faria parte de uma nova nobreza ou de uma nobreza recente, beneficiando do facto de serem cada vez mais requisitados pela máquina burocrática e igualmente do próprio alargamento do campo e conceito da nobreza. Cf. RODRIGUES, José Damião, "A Estrutura Social”, in Nova História de Portugal, Direcção de Joel Serrão e A.H. de Oliveira Marques, Lisboa, Editorial Presença, 2001, vol. VII, p. 429.

${ }^{14} \mathrm{O}$ facto de ele ser de origens plebeias levou-o, provavelmente, a solicitar a licença de advogado, pois não poderia ocupar cargos no judiciário régio (ele não seria [ou não foi] aprovado na leitura dos bacharéis).

${ }^{15}$ ANTT, HOC, Letra A, Maço 32, doc. 1.

${ }^{16} \mathrm{Cf}$. Ofício do Ouvidor de Goiás, Francisco de Atouguia, ao Secretário de Estado da Marinha e Ultramar, Vila Boa, 29 de maio de 1760, AHU, Goiás, cx. 17, doc. 988.
} 
uma eventual possibilidade de ascensão social. Não que o futuro de António de Menezes tivesse de passar necessariamente pela atividade mineradora. Mas, por decreto de 1750, a Coroa estipulava que todos aqueles que entregassem oito ou mais arrobas de ouro nas casas de fundição das capitanias correspondentes no espaço de um ano estariam em condições de requerer uma mercê nobilitante, neste caso o hábito da Ordem de Cristo, independentemente de serem ou não mineiros. ${ }^{17}$

Ora, António Teles de Menezes estaria certamente a par do referido decreto e conheceria até situações de negociantes de grosso trato que, estabelecendo ligações comerciais com as regiões de mineração, transacionavam os produtos que levavam do Rio de Janeiro ("bens secos e molhados" e sobretudo escravos) com os mineiros, recebendo como moeda de troca quantias consideráveis de ouro em pó, que eram posteriormente canalizadas para as casas de fundição. Quiçá, uma vez bem estabelecido e estabilizado em Goiás, não poderia ele enveredar por esse caminho, aplicar parte das suas economias nesse rendoso comércio com os portos do mar e receber em troca o precioso metal amarelo que o poderia catapultar para a categoria de Cavaleiro de Cristo? ${ }^{18}$

Talvez nunca saibamos se todas essas cogitações já estavam bem presentes na decisão de António Teles de Menezes de rumar para Vila Boa de Goiás, mas a verdade é que elas viriam a concretizar-se a posteriori. ${ }^{19}$

Assim, em 1770, pouco mais de uma década decorrida da sua chegada à capitania de Goiás, ele requereu o hábito da Ordem de Cristo, pela entrega de mais de 8 arrobas de ouro na casa de fundição de Vila Boa. Mas o monarca solicitava que o governador de Goiás confirmasse o pedido de António Teles de

\footnotetext{
${ }^{17}$ Lei dando nova forma à arrecadação dos Quintos", 3 de dezembro de 1750, António Delgado da Silva, in Colecção da Legislação Portuguesa, redigida pelo Desembargador António Delgado da Silva, Legislação de 1750-1762, Lisboa, Typografia Maigrense, 1830, pp. 26.

${ }^{18}$ Apesar de não estar explícito que a mercê a conceder pela Coroa pelo serviço prestado era o hábito da Ordem de Cristo, de facto foi esta a mercê solicitada de forma recorrente. Segundo Roberta Stumph, tal aconteceu porque esta era uma mercê bastante apetecível para os que alimentavam propósitos de demarcação social e porque só com uma mercê tão apelativa e cobiçada o monarca conseguia mobilizar os seus vassalos em torno de uma causa comum e incentivá-los a entregar o ouro de uma forma continuada nas casas de fundição. Cf, STUMPH, op. cit., pp. 217-218.

${ }^{19}$ Segundo alguns dos mais renomados historiadores brasileiros da atualidade, as estratégias mais usuais de nobilitação no espaço colonial brasileiro passavam pelo exercício de cargos nobilitantes (caso das câmaras), pelo obtenção de mercês como o hábito da Ordem de Cristo, bem complementados por uma situação de abastança económica, que permitiria viver segundo os padrões da nobreza. Cf., entre outros, FRAGOSO, João, "A formação da economia colonial no Rio de Janeiro e de sua primeira elite senhorial (séculos XVI e XVII)", in O Antigo Regime nos trópicos. A dinâmica imperial portuguesa (séculos XVI-XVIII), Rio de Janeiro, Civilização Brasileira, 2001, pp. 29-71; BICALHO, Maria Fernanda, "Conquista, Mercê e Poder Local: a nobreza da terra na América portuguesa e a cultura política do Antigo Regime", in Almanack brazilense, Rio de Janeiro, UFF, nov. 2005, ํㅡㄹ, pp. 21-34.
} 
Menezes e os dados nele contidos, razão pela qual foram examinados os livros da Intendência e se concluiu pela legitimidade do requerimento. ${ }^{20}$ Todavia, das provanças que se fizeram pela Mesa de Consciência e Ordens, em 1778, resultaram os impedimentos da "falta de qualidade" de alguns dos ascendentes do habilitando, a saber: "O Avo Materno, sendo ultimamente Lavrador de terras suas, nos seus princípios foi Negociante comprando e vendendo vários géneros que transportava de terra em terra, a Avô materna era mulher de segunda condisão". ${ }^{21}$

António Teles de Menezes tinha ascendência plebeia, isso ficou bem patente no seu processo de provanças. Mas tal constatação não o inibiu de prosseguir os seus intentos e, tal como outros o fizeram, recorreu com uma petição à rainha D. Maria, alegando que os mencionados impedimentos eram "tão ténues que cabião na Real Grandeza de Vossa Magestade a dispensa deles". ${ }^{22}$ Lembrava, igualmente, o quanto havia contribuído para a Fazenda Real com os direitos de entrada pagos como homem de negócio que era, cujo ofício se estendia às Minas Gerais. ${ }^{23}$

Pelo que se constata, António Teles de Menezes já não exercia apenas a função de advogado, diversificara as suas atividades e tornara-se igualmente um homem de negócios. E teria sido, muito provavelmente, no exercício da atividade mercantil, fornecendo bens aos mineiros, que angariara o ouro necessário para solicitar a mercê da Ordem de Cristo. José Rodrigues Freire, cavaleiro da Ordem de Cristo, foi testemunha no processo de provanças, realçando que o habilitando, mesmo quando se envolveu na área comercial, negociando fazendas de lã, o fazia por atacado e nada por miúdo, possuindo caixeiros que para si trabalhavam. ${ }^{24}$ Manuel Cardoso Pinto, outra influente figura a nível local e que também solicitara o hábito da Ordem de Cristo, ia até mais longe nos seus comentários, ao afirmar que o justificante, ao envolver-se na atividade mercantil, "paçara a fazer comercio para as principais praças daquele continente, o qual hera todo em partidas avultadas, tendo nas mesmas [praças] hum grande credito, como também na mesma dita Villa [Boa

\footnotetext{
${ }^{20}$ Carta do governador de Goiás, Vila Boa, 20 de outubro de 1772, AHU, CU, cx. 26., doc. 1696.

${ }^{21}$ ANTT, HOC, Letra A, maço 32, nº1, Lisboa, 27 de maio de 1778. Como se pode constatar, o processo foi-se arrastando por quase 10 anos e isso explica, em grande medida, que muitos requerentes fossem desistindo de o conduzir a bom termo à medida que os entraves burocráticos iam surgindo.

${ }^{22}$ Idem.

${ }^{23}$ Idem.

${ }^{24}$ ANTT, ibidem, f. 4.
} 
de Goiás], por paçar por huma das Principais cazas de comércio e se tratar à Ley da Nobreza". ${ }^{25}$

O sucesso de António Teles de Menezes no domínio comercial, semelhante ao de tantos outros, encontra justificação no contexto de uma crescente integração da capitania de Goiás nas dinâmicas comerciais do Brasil colonial. ${ }^{26}$ É, igualmente, importante frisar a existência de uma linha de demarcação que separava o comércio que conferia dignidade e prestígio nas sociedades tradicionais do Antigo Regime, o comércio de grosso trato, e preferencialmente que dispensasse qualquer tipo de envolvimento individual em tarefas que pudessem ser interpretadas como manuais ou mecânicas, daquele outro comércio que, pelas características inversas, comportava uma conotação pejorativa e poderia, inclusivamente, revelar-se um poderoso obstáculo a qualquer pretensão de promoção social. ${ }^{27} \mathrm{E}$ era nessa questão de primacial importância que a posição do justificante não só era salvaguardada, como saía reforçada. Seja como for, em virtude dos impedimentos já mencionados, o hábito de cavaleiro de Cristo foi-lhe atribuído em 1778 mediante o pagamento de uma multa de 20 moedas. $^{28}$

Deve sublinhar-se que a decisão de se estabelecer na capitania de Goiás era já uma aposta ganha. Tornara-se Cavaleiro da Ordem de Cristo, o que lhe conferia, para todos os efeitos, um estatuto nobiliárquico, não o de uma autodenominada "nobreza da terra", mas de uma nobreza devidamente reconhecida pelo centro político sediado em Lisboa, ou seja, pela Coroa. ${ }^{29}$ Este facto é tanto mais de enaltecer, quando sabemos que dos quarenta indivíduos que solicitaram o hábito da Ordem de Cristo de acordo com o estipulado no

\footnotetext{
${ }^{25}$ Ibidem, fl. $7 \mathrm{v}$.

${ }^{26}$ Assim o sublinha Mary Karasch, quando defende que a capitania de Goiás, mais do que uma periferia do comércio colonial brasileiro, foi um centro regional importante, que se valorizou graças à exploração mineira e à sua localização geográfica. Estava perfeitamente interligada com a economia atlântica pelo contato assíduo com os portos de mar mais importantes (Bahia e Rio de Janeiro), e em interação com o Mato Grosso, São Paulo e Pará. KARASCH, Mary, “The Periphery of the Periphery? Vila Boa de Goiás, 17801835", in Negotiated Empires: centers and peripheries in the Americas, 1500-1820, New York-London, Routledge, 2002, pp. 143-169.

${ }^{27}$ Segundo Jorge Pedreira, desde o século XVII que os comerciantes de grosso trato vinham reclamando uma condição jurídica diferenciada da dos comerciantes de loja aberta, associados a uma ocupação mecânica, para assim obterem outro reconhecimento social. Cf. PEDREIRA, Jorge, Os Homens de negócio da Praça de Lisboa de Pombal ao Vintismo (1755-1822. Diferenciação, reprodução e identificação de grupo social, Dissertação de Doutoramento, Universidade Nova de Lisboa, Lisboa, 1995, pp. 80 e seguintes.

${ }^{28}$ ANTT, HOC, Letra A, maço 32, nº 1 . O pagamento daquele valor surgia com compensação para os impedimentos que apresentava.

${ }^{29}$ Segundo R. Stumpf, aqui residia a diferença entre "nobres da terra" (nobreza tática) e a que era agraciada pela Coroa com uma mercê nobilitante, (nobreza legal). Cf. STUMPF, op. cit., pp. 59-63.
} 
decreto de 1750, apenas oito viram satisfeitas as suas pretensões e António de Menezes estava entre o restrito grupo dos eleitos. ${ }^{30}$

O próprio facto de no seu processo de provanças terem figurado testemunhos como o do ex-governador de Goiás, D. Álvaro José Xavier, Conde de São Miguel, é sintomático do prestígio e reconhecimento que António Teles de Menezes vinha adquirindo a nível local.

Mas o percurso ascensional de Teles de Menezes não se ficou por aqui. Ele tinha, igualmente, ambições públicas e fez por ocupar cargos importantes a nível local. É essa trajetória que iremos reconstituir.

Em 1770, o secretário do governo de Goiás, Diogo Luís de Sottomayor, escrevia para a Corte a solicitar a continuidade no cargo que exercia, dando conta de que havia outro concorrente para o mesmo, o letrado António de Sousa Teles de Menezes, que vivia do comércio e pretendia aproveitar a conjuntura existente para assumir a secretaria do governo. ${ }^{31}$ A que conjuntura se referia ele? Decerto, ao recente e inesperado falecimento do governador João Manuel de Melo, provocando, temporariamente, um vazio do poder. Mas o secretário do governo de Goiás não se limitava a constatar esse interesse de António de Menezes pelo cargo em questão, procurando igualmente veicular uma imagem negativa do mesmo: "Afirmo a V. Exc ${ }^{a}$ que o dito letrado tem tal genio, que certamente tornarião a ressurgir nesta capitania as antigas discórdias. O Dr. Desembargador António José, Ouvidor que foi nesta comarca o conhese com mais luz". ${ }^{32}$ Diogo Sottomayor, para se descartar de um rival e preservar o cargo, mencionava que António Teles de Menezes não teria perfil para o mesmo, que seria propenso a fomentar um clima de discórdias a nível local, e invocava o nome do ex-ouvidor de Goiás para conferir maior legitimidade às suas insinuações.

Até que ponto eram essas insinuações legítimas? Não o sabemos. O que parece óbvio é que António Teles de Menezes se mostrava bastante determinado em construir um percurso de ascensão social pelo exercício de diversos cargos à escala local para os quais se julgava habilitado e que ele sabia serem fator de prestígio e de reconhecimento social. E que tal situação ter-lhe-á custado, certamente, algumas inimizades.

\footnotetext{
${ }^{30} \mathrm{Cf}$. MENDONÇA, Luís, Viver à lei da Nobreza. Trajetórias Sociais dos 'Cavaleiros do Ouro' numa Capitania de Mineração (Goiás entre 1750 e 1800), dissertação de mestrado defendida e aprovada em 2015, FLUL, [disponível online, URL:http://www.repositorio.ul.pt/bitstream/10451/23358/1/ulfl199963_tm.pdf].

${ }^{31}$ Ofício do Secretário do Governo de Goiás, Diogo Luís Sottomayor ao S.E.M.U., solicitando a sua conservação no cargo. Vila Boa, 18 de março de 1770, AHU, CU, Goiás, cx. 25, doc. 1595.

${ }^{32}$ Idem.
} 
O certo é que, no mesmo ano de 1770, ele assumia-se como candidato ao cargo de Intendente da casa de fundição de São Félix, um cargo que conferia prestígio e poder a quem o desempenhava, pelas amplas responsabilidades fiscais que lhe estavam associadas, ${ }^{33} \mathrm{e}$, para convencer a Coroa do seu merecimento, mencionava a lista de serviços e cargos já desempenhados na capitania de Goiás: tivera vários ofícios na ouvidoria-geral e correição de Vila Boa; fora fiscal da casa de fundição de Vila Boa, vereador da câmara local, procurador da Corte (associado a questões fiscais) e sem auferir qualquer ordenado; e, por fim, entregara na casa de fundição de Vila Boa, no espaço de um ano, mais de 8 arrobas de ouro. Em suma, "tendo atenção ao referido e documentos juntos pertende que V. Magestade lhe faça merce da Intendência da Real casa de fundição de São Félix da comarca de goyazes". ${ }^{34}$

Entre 1776 e 1782, António Teles de Menezes foi procurador do contratador das entradas João Rodrigues de Macedo e arrematante do mesmo para Minas Gerais, Goiás, Mato Grosso e São Paulo. Foi precisamente nessa qualidade de procurador que ele se insurgiu contra a Junta da Fazenda Real de Goiás, ${ }^{35}$ por esta ter estabelecido com Joaquim Pereira Gaia Peçanha um contrato em que este ficava a monopolizar a produção e comercialização de solas em toda a capitania, retirando a qualquer particular a liberdade e direito de poder curtir e vender sola. ${ }^{36}$ Mas o pior é que tal determinação da Junta da Fazenda era oposta e claramente prejudicial às condições do contrato das entradas do seu constituinte, que permitiam "a liberdade dos negociantes venderem os seus géneros como, a quem, e pello preço, que mais conta lhes fizer depois de pagarem os direitos das entradas". ${ }^{37}$

No caso concreto, esta situação ficava seriamente comprometida, na medida em que sendo o tal Peçanha o único fabricante de solas, só restava aos negociantes vender a matéria-prima ao mesmo e "por preço ínfimo". Daí resultaria que muitos negociantes evitariam vir vender a sola a Vila Boa, por

\footnotetext{
${ }^{33}$ Cf. CHAVES, Cláudia, “A administração fazendária na América portuguesa: a Junta da Real Fazenda e a política fiscal ultramarina nas Minas Gerais”, in Almanack. São Paulo, Guarulhos, $1^{\circ}$ semestre de 2013, n. 05, p. 81-96.

${ }^{34}$ Requerimento de António de Sousa Teles de Menezes ao rei D. José solicitando a mercê de intendente da Casa de Fundição de São Félix. Vila Boa, 18 de agosto de 1770, AHU, Goiás, Cx. 25, doc. 1609.

${ }^{35}$ As Juntas da Fazenda Real eram responsáveis pela arrematação dos contratos das entradas e, apesar de prestarem contas ao Erário Régio, gozavam de uma certa autonomia que lhes permitia servir interesses particulares, traduzindo-se muitas vezes em "favoritismos, apadrinhamentos, irregularidades nas contas, ausência de transparência nos contratos e, finalmente, prejuízos no erário". CHAVES, op. cit., p. 84.

${ }^{36} \mathrm{Cf}$. Carta do bacharel António Teles de Menezes ao rei D. José sobre o procedimento da Junta da Fazenda Real de Goiás, Vila Boa, 10 de agosto de 1777, AHU, CU, Goiás, cx. 29, doc. 1884.

${ }^{37}$ Idem.
} 
deixar de ser economicamente compensador, e o contrato das entradas conheceria um grave prejuízo, uma vez que fora arrematado por um valor que não previa a alteração das "regras do jogo" ${ }^{38} \mathrm{Em}$ suma, o direito de exclusividade concedido a Joaquim Peçanha no fabrico e comercialização da sola faria, de acordo com as leis da oferta e da procura, baixar o preço da matéria-prima, levaria à diminuição da afluência de comerciantes à capitania e, por arrastamento, à diminuição dos rendimentos dos direitos de entrada. E era essa situação que António de Menezes, enquanto representante do contratador das entradas, contestava e pretendia ver alterada, mas temos dúvidas de que com resultados práticos, até porque o referido contrato fora feito por um período de 10 anos.

Em 1781, achando-se vago o posto de Capitão da Companhia da Nobreza de Vila Boa de Goiás, os oficiais da Câmara propuseram para o lugar, por pluralidade de votos, o Dr. António de Sousa Teles de Menezes, por ser uma pessoa bem estabelecida no local e "concorrerem nelle todas as circunstâncias que o fazem digno de ser preferido na ocupação do dito posto". ${ }^{39}$ Assim sendo, ele passava a ocupar um novo posto, que lhe permitia usufruir "de todas as honras, privilégios, graças, liberdades, franquezas, e izencõens que em razão delle lhe pertencem". ${ }^{40}$

Em 1783, era a vez de disputar o cargo de capitão-mor da comarca de Vila Boa, entretanto vago. A câmara de Vila Boa propôs três nomes e pela seguinte ordem: primeiro, Francisco Pereira, capitão de auxiliares e juiz ordinário; em segundo lugar, António de Sousa Teles de Menezes, cavaleiro professo da Ordem de Cristo e recentemente promovido a capitão da companhia da Nobreza; e, por fim, António Gomes de Oliveira, capitão das ordenanças, um dos homens mais ricos da capitania e que ocupara alguns cargos públicos. ${ }^{41}$ O capitão-general Tristão da Cunha Meneses ignorou a ordem das propostas feitas pela câmara, nomeando para o cargo António Gomes de Oliveira, o que, na opinião de António de Menezes, um dos supostos lesados nessa escolha, configurava uma situação "clara a infracção das Leys, e o suborno em que foi

\footnotetext{
${ }^{38}$ Idem.

${ }^{39}$ Requerimento de António Teles de Menezes à Rainha, solicitando confirmação da carta patente no posto de capitão da nobreza de Vila Boa, 15 de julho de 1782, AHU, CU, Goiás, cx. 33, doc. 2066.

${ }^{40}$ Idem.

${ }^{41}$ Carta de António de Sousa Teles de Menezes à rainha, sobre as queixas contra o governador Tristão da Cunha Meneses, Vila Boa, 22 de setembro de 1783, AHU, CU, Goiás, cx. 34, doc. 2124.
} 
promovido neste posto o dito Oliveira". ${ }^{42}$ A própria câmara acabaria por ser pressionada a aceitar aquela escolha.

António de Menezes estava indignado com o desfecho de tal situação, primeiro, porque o parecer dos camaristas não fora respeitado, e, segundo, porque se achava a pessoa mais indicada para ocupar o cargo, chegando a afirmar "estar três vezes mais bem habilitado que nenhum dos nomeados". ${ }^{43}$ Acresce ainda que, no seu entender, o escolhido do governador, António Gomes de Oliveira, não obstante ser rico, era "marchante", um açougueiro, entregava carne ao povo "em cortes seus próprios", ainda que com o auxílio de caixeiros e escravos. Assim sendo, exercia uma função que não era de todo prestigiante, traduzindo um "impedimento mecânico" e, por conseguinte, comprometedora para quem se apresentava com aspirações políticas e de promoção social. Em suma, concluía António de Menezes, o ocorrido "parece tão incompatível, como injurioso a hum posto de tanta honra e autoridade". ${ }^{44}$

o que teria, então, levado o governador Tristão da Cunha Meneses a dar preferência a António Gomes de Oliveira? Na opinião do próprio António de Menezes, tal devia-se ao facto de ele ocupar o cargo de governador há pouco tempo, evidenciando falta de conhecimento, mas principalmente resultava da influência "nefasta" que sobre ele exerciam dois homens próximos da sua governação, ambos genros do dito António Oliveira. Um deles era seu secretário particular e o outro, José Pinto da Fonseca, já colaborara com o governador José de Almeida de Vasconcelos, sendo um homem ardiloso, que privilegiava os enredos, as intrigas palacianas e era causador de tantas desordens. ${ }^{45}$

António Teles de Menezes não desistiu. Perante uma situação em que se considerava claramente injustiçado, decidiu apelar para a rainha para que esta anulasse a decisão do governador, promovendo-o no dito posto de capitão-mor, alegando ser um "Leal Vassalo, que tão útil tenho sido aos interesses de V. Magestade no manejo de mais avultado negócio, que do Rio de Janeiro tendo metido nesta comarca, pagando fielmente os direitos e à Real Fazenda

\footnotetext{
${ }^{42}$ Idem.

${ }^{43}$ Idem.

${ }^{44}$ Idem. Convém acrescentar que, apenas seis anos antes, Teles de Menezes referia-se de forma elogiosa a António Gomes de Oliveira e sobre ele afirmava o que "este homem he o vassalo mais bem estabelecido, e interessante que V. Magestade tem nesta comarca”. Carta do bacharel António de Sousa Teles de Menezes ao rei D. José sobre o procedimento da Junta da Fazenda Real de Goiás..., Vila Boa, 10 de agosto de 1777. AHU, Goiás, cx. 29, doc. 1884. A questão é que, então, António de Menezes era procurador do contratador das entradas e António Oliveira surgia como um potencial aliado, ao passo que, em 1783, os dois homens estavam de lados opostos da barricada e aí a riqueza deixava de ser, por si só, uma qualidade.

${ }^{45}$ Carta de António de Sousa Teles de Menezes à rainha, sobre as queixas contra o governador Tristão da Cunha Meneses, Vila Boa, 22 de setembro de 1783, AHU, CU, Goiás, cx. 34, doc. 2124.
} 
avultados pagamentos do contrato das Entradas de 6 anos que administro" ${ }^{46}$ António Teles de Menezes não viu satisfeitas as suas pretensões, mas, em 1786, vagando novamente o lugar por falecimento de António Gomes de Oliveira, a câmara de Vila Boa, desta vez por unanimidade de votos e sem qualquer tipo de interferências, propunha para o cargo o mesmo António de Menezes, que, pela sua nobreza e honra, passava a ser merecidamente o capitão-mor de Vila Boa, um cargo tanto mais apetecível por ser vitalício, ${ }^{47}$ correspondendo à consumação plena da sua trajetória política e de ascensão social na capitania de Goiás.

Nesse espaço temporal, ele já havia ocupado cargos na câmara de Vila Boa. Em 1785, na qualidade de juiz ordinário, dirigia uma carta à Rainha D. Maria I (em conjunto com os demais oficiais da câmara), na qual tecia rasgados elogios à postura do novo governador, Tristão da Cunha Meneses, ${ }^{48}$ por contraste com a dos seus antecessores. Sobre o modo de governar do novo capitão-general dizia-se o seguinte:

\begin{abstract}
"Este sistema utilíssimo de governar, procurando a tranquilidade dos Povos, e animando-os nas suas differentes ocupaçoens, tão necessario a situação, e ao estado desse Paíz, he o que practica felizmente nesta Capitania o Governador actual, incluindo no mesmo sistema até o projecto de pacificação pelos meyos mais suaves, e brandos as desordens, e rixas, que naturalmente versão entre os moradores, e que são talvez mais frequentes á proporção que he mais pobre, e arrastado o Paiz". ${ }^{49}$
\end{abstract}

O que deve sublinhar-se através da trajetória de António Teles de Menezes é que ele terá percecionado, desde muito cedo, que o enriquecimento por via do negócio, aliado à sua condição de bacharel em advocacia, essa espécie de simbiose perfeita entre riqueza e viver à lei da nobreza, entre o potencial económico e uma boa formação académica, conferia-lhe uma larga vantagem para disputar e ocupar uma série de cargos a nível local, inclusive os mais importantes, para além de ostentar a insígnia de cavaleiro de Cristo. Assim sendo, ele representa um dos melhores exemplos, se não o melhor, de

\footnotetext{
${ }^{46}$ Carta do bacharel António de Sousa Teles de Menezes à Corte sobre o procedimento da Junta da Fazenda Real de Goiás, Vila Boa, 10 de agosto de 1777, AHU, CU, Goiás, cx. 29, doc. 1884.

${ }^{47}$ Requerimento de António Teles de Menezes à Rainha, solicitando confirmação no posto de capitão-mor das Ordenanças de Vila Boa, Goiás, 19 de julho de 1787, AHU, CU, Goiás, cx. 36, doc. 2234.

${ }^{48}$ Curiosamente, Tristão da Cunha Meneses era irmão de Luís da Cunha Meneses, com quem António de Menezes mantivera um braço de ferro. E um dos oficiais da câmara de então dava pelo nome de Joaquim Pereira Gayo Peçanha, com quem António de Meneses já mantivera um clima de conflitualidade.

${ }^{49}$ Carta dos oficiais da Câmara de Vila Boa de Goiás à rainha, solicitando a permanência do governador, Vila Boa, 30 de dezembro de 1785, AHU, CU, Goiás, cx. 36, doc. 2194.
} 
um percurso de ascensão social e política na capitania de Goiás na segunda metade de Setecentos, culminado com a sua eleição para o posto de capitão-mor, que era "conferente" e garante de nobreza.

Mas, nos princípios do século XIX, o capitão-mor de Vila Boa (António de Menezes) foi envolvido numa "insurreição" dos camaristas de Vila Boa contra o governador João Manuel de Meneses. Perante o clima de conflitualidade instalado na capitania, João Manuel de Meneses acabou por ser afastado do cargo por determinação régia. Enquanto isso, decorreu uma devassa para apurar responsabilidades, concedendo-se um indulto a quase todos os insurretos, nomeadamente a todos os camaristas envolvidos na "conjura". 0 capitão-mor Teles de Menezes terá sido uma das poucas exceções, sob uma suposta acusação de que "de inteligência com o ouvidor [Manuel Joaquim de Aguiar] traçavam passar lhe as mãos o governo de sucessão". ${ }^{50}$

Afinal, de que era acusado António Teles de Menezes? Teria assumido um papel de maior protagonismo na referida insurreição ou sido um dos seus mentores, merecendo, por isso, uma pena mais pesada da justiça? Teria planeado uma espécie de "golpe político", de forma a aproveitar-se da destituição do governador, como sugere o desembargador Sousa Leal? Mas isso seria, de todo, improvável, pois, como observa Fernando Lobo Lemes, não parece ter havido em todo esse processo qualquer tentativa de "usurpação do poder real". ${ }^{51}$

Apesar de o desembargador dos agravos António Luís de Sousa Leal ter admitido ser quase impossível apurar a verdade, o certo é que António de Sousa Teles de Menezes seria pronunciado e preso, pois era " forçoso acautelar com sequestro a distracção dos bens". ${ }^{52}$ Faleceria 8 dias depois, a 22 de agosto de 1804.

Paulo Bertran interroga-se sobre as razões que terão conduzido ao referido desfecho e inclina-se claramente para uma explicação bem distinta: o que esteve na base da detenção de António Teles de Menezes foi uma carta por ele enviada à Rainha vários anos antes, mas que nunca chegara ao destino..$^{53} \mathrm{Em}$

\footnotetext{
${ }^{50}$ Ofício do desembargador dos agravos António de Luís de Sousa Leal, Vila Boa, 30 de junho de 1804, AHU, CU, Goiás, cx. 47, doc. 2732.

${ }^{51}$ LEMES, Fernando Lobo, A Oeste do Império - Dinâmica da Câmara Municipal na última periferia colonial: um estudo das relações de poder nas minas e capitania de Goiás (1770-1804), dissertação de mestrado, UFG, Goiânia, 2005, p. 110 [online, acesso a 10 de nov. de 2013, URL:http://wwwpos.historia.ufg.br/up/113/o/LEMES. pdf]. Uma das fontes em que Fernando Lobo Lemes se baseia para reconstituir todo esse processo político é José de Alencastre, Anais da Província de Goiás. Goiânia, SUDECO, 1979.

${ }^{52}$ Ofício do desembargador dos agravos ..., Vila Boa, 6 de set. de 1804, AHU, Goiás, cx. 48, doc. 2744.

${ }^{53}$ Carta do Capitão-mor de Vila Boa, Dr. António Teles de Menezes, à Rainha, in BERTRAN, Paulo (org.),
} 
1804, foi encontrada casualmente pelo desembargador Sousa Leal no Rio de Janeiro. O seu teor determinou a prisão e sequestro de bens do Capitão-Mor de Vila Boa, que faleceu nas masmorras daquela vila. ${ }^{54}$

Partindo do pressuposto de que tal é verdade, encontrar uma carta em que António Teles de Menezes denunciava de forma contundente a prepotência e os abusos de poder dos principais agentes políticos da Coroa na capitania de Goiás e somar tal facto à insurreição ocorrida quinze anos depois contra o governador João Manuel de Meneses, poderá ter levado o desembargador Sousa Leal a pensar que António Teles de Menezes seria um foco de instabilidade política ou colocava em causa um clima de normalidade política na capitania. E que, face a isso, a solução mais adequada era a sua detenção. Estamos, todavia, no domínio das meras conjeturas, que carecem, obviamente, de uma maior fundamentação.

\section{António de Sousa Teles de Menezes e a conjuntura de finais do século XVIII}

Chegou o momento de procurar conhecer melhor o entendimento do Cavaleiro da Ordem de Cristo António de Sousa Teles de Menezes sobre diversas questões que afetavam a capitania de Goiás no último quartel do século XIX. E é basicamente à luz da mencionada carta de $1789^{55}$ que podemos ter uma perceção clara de como António de Menezes via os problemas do seu tempo, do diagnóstico que fazia e das soluções apresentadas para a sua superação. Desde logo, chamamos a atenção para a data do texto: 1789 . Se, nas fontes consultadas, não foram detetados indícios de qualquer contágio com o que ocorreu na capitania de Minas Gerais na conjuntura da designada "Inconfidência Mineira", esta carta pode muito bem ter sido redigida como uma resposta a esse evento, demarcando posições, mas também denunciando problemas a que a Coroa teria de atender.

O nosso enfoque foi colocado nas questões económicas, sociais e políticas, sendo cada uma delas precedida de um enquadramento, até para se perceber se havia uma sintonia entre a visão do capitão-mor de Goiás e a maioria dos homens do seu tempo, ou se, pelo contrário, havia algo de inovador no seu discurso e nas suas propostas.

\footnotetext{
Notícia Geral da capitania de Goiás em 1783, Goiânia-Brasília, Editora da Universidade Católica de Goiás-Editora da Universidade Federal de Goiás-Solo Editores, 1997, Tomo II, pp. 31-47.

${ }^{54}$ Idem, p. 33.

${ }^{55}$ BERTRAN, op. cit., pp. 31-47.
} 
Comecemos, então, pelos aspetos económicos e, muito particularmente, pelo declínio da mineração, um dos factos que mais afligia os espíritos da época à medida que o século XVIII se ia aproximando do seu término. As autoridades de Goiás sempre tinham revelado uma clara perceção de que a prosperidade da capitania estava absolutamente associada à prosperidade das suas minas e que a diminuição progressiva da produção mineira arrastaria Goiás para uma inevitável situação de decadência. E a verdade é que, depois de ter atingido o seu apogeu entre 1750 e 1760, a mineração na capitania foi decrescendo progressivamente, até atingir níveis muito preocupantes a partir de meados da década de setenta, passado os quintos reais de 2500 marcos em 1755, para cerca de 500 marcos em $1790 . .^{56}$

Assim, à medida que os anos passavam, mais preocupante era o panorama da capitania, mais dramática era a situação dos mineiros, maiores as apreensões das autoridades quanto ao futuro das minas. Sendo a mão de obra escrava a principal mola impulsionadora da mineração, o endividamento progressivo dos mineiros tornava cada vez mais problemática a aquisição de escravos, fundamental para manter os níveis de mineração. Chegara uma altura em que os negociantes de escravos se recusavam a vendê-los aos mineiros de Goiás, completamente descredibilizados por sucessivas situações de incumprimento, preferindo conduzi-los para a capitania de Mato Grosso. ${ }^{57}$

Os testemunhos abundam, mas, ao reproduzi-los, correríamos sérios riscos de nos tornarmos repetitivos. Diríamos, então, que se estabeleceu uma espécie de círculo vicioso, que poderíamos sintetizar do seguinte modo: à medida que se acentuou a escassez de ouro nas minas, assistiu-se a um endividamento progressivo dos mineiros; cada vez mais endividados, estes não tinham capacidade para adquirir escravos, quando não perdiam mesmo os escravos que já haviam adquirido a crédito; por conseguinte, com a diminuição drástica da mão-de-obra escrava, a exploração mineira era cada vez mais afetada. Esta situação foi-se repetindo continuamente até atingir um ponto em que a mineração se tornou insignificante, uma mera atividade de garimpeiros, sem expressão nos rendimentos da capitania ou nos quintos reais.

Teria sido possível uma solução para inverter essa situação? Os contemporâneos dos acontecimentos estavam convencidos de que, atendendo ao estado miserável da capitania e à escassez de ouro nas terras minerais

\footnotetext{
${ }^{56}$ Cf. PALACIN, Luís, Goiás 1722-1822, Estrutura e Conjuntura numa Capitania de Minas, $2^{\mathrm{a}}$ edição, Goiânia, Oriente, 1976, pp. 212-213.

${ }^{57}$ Ofício do governador de Goiás ao Secretário de Estado da Marinha e Ultramar, Vila Boa, 7 de setembro de 1788, AHU, CU, Goiás, cx. 37, doc. 2279.
} 
exploradas, a solução estaria nas mãos da própria Coroa: liberalizar aos mineiros a exploração dos rios Pilões e Claro, onde constava existir ouro em abundância. ${ }^{58}$ Era uma reivindicação que já se prolongava por várias décadas e que teimava em não ser desbloqueada. Quanto mais se afundava a situação da capitania, mais frequentes eram os apelos para que a Coroa se dignasse a conceder essa mercê aos moradores de Goiás. ${ }^{59}$

Segundo o governador Luís de Meneses, o próprio “indulto” concedido de boa-fé pela Coroa aos mineiros na cobrança das respetivas dívidas acabaria por produzir efeitos perversos, na medida em que os convidava a incorrer em situações de incumprimento, ao mesmo tempo que incentivava os fornecedores de mão de obra, como forma de precaução, a inflacionar o preço dos escravos que vendiam, ou, pura e simplesmente, a deixar de fornecê-los aos mineiros. ${ }^{60}$

A verdade era essa. Nas condições da época, a situação de "prosperidade" estava totalmente dependente da abundância de ouro nas minas. 0 difícil acesso das minas ao litoral (nunca resolvido), as rudimentares "técnicas" de exploração mineira, o elevado preço dos escravos que chegavam dos portos do mar, a importação de quase todos os bens consumidos nas minas (igualmente por preços bastante inflacionados), fruto da profunda convicção de que a mineração era bem mais rentável do que a agricultura, a própria asfixia do setor agrícola, mercê de dízimos elevados e cobrados, por vezes, de forma arbitrária, os interesses dos contratadores das entradas, que viam os seus lucros aumentarem na proporção dos bens entrados na capitania, tudo isso explica que a estrutura (assente em tão frágeis alicerces) se desmoronasse quando a conjuntura deixasse de ser favorável (o boom da exploração mineira). E foi isso, efetivamente, o que aconteceu.

E o que pensava sobre tudo isso António Teles de Menezes, ele que viera para Goiás ainda no período áureo da produção aurífera, que alcançara a nobilitação graças à abundância de ouro na capitania? Os argumentos por si apresentados para explicar o declínio da mineração, e que se traduzia numa decadência económica generalizada, ${ }^{61}$ parecem não se descolar do discurso

\footnotetext{
${ }^{58}$ Carta do procurador da Coroa e vereador da Câmara de Vila Boa à rainha, Vila Boa, 24 de agosto de 1783, AHU, CU, Goiás, cx. 34, doc. 2118.

${ }^{59} \mathrm{Cf}$. Ofício do governador de Goiás ao S. E. M. Ultramar, Vila Boa, 12 de fevereiro de 1787, AHU, CU, Goiás, cx. 36, doc. 2222.

${ }^{60} \mathrm{Cf}$. Ofício do governador de Goiás ao S. E. M. Ultramar, Vila Boa, 8 de julho de 1780, AHU, CU, Goiás, cx. 32, doc. 2001.

${ }^{61}$ Certa historiografia vem colocando cada vez mais dúvidas em relação à situação de decadência vivida em Goiás a partir das últimas décadas do século XVIII e tem a sua principal representante em LOIOLA, Maria
} 
que vinha sendo veiculado nos meios oficiais. Enumerava alguns aspetos que haviam contribuído para o referido declínio, destacando fatores como a permanência do privilégio de perdoar as dívidas aos mineiros com mais de 30 escravos, a falta de trabalho regular de muitos mineiros e proprietários de escravos, a que acrescentava a vadiagem e ociosidade em que se encontrava grande parte da população negra, mestiça e pardos forros. ${ }^{62}$ António de Menezes estava convencido, e nisso estava em total consonância com o discurso oficial, de que a concessão do privilégio da trintena (não execução dos mineiros com mais de 30 escravos) acabou por ter efeitos bastantes perniciosos para a economia da capitania:

Por esta causa quebraram muitos negociantes com grossos cabedais, outros deixaram de vender mais escravos fiados a Mineiros privilegiados com o receio de demandas, e pouco e pouco diminuiu a entrada dos escravos para esta Capitania, e se aumentou para a de Cuiabá e Mato Grosso, para onde até hoje entram todos os anos grandes comboios de escravos e fazenda, pela prontidão do pagamento. ${ }^{63}$

O capitão-mor de Goiás também se juntava ao numeroso grupo dos que julgavam que era da máxima importância franquear aos mineiros os Rios Pilões e Rio Claro, até porque a escassez de diamantes aí existentes não justificava o prolongamento da sua interdição. ${ }^{64}$

Ao contrário de alguns, que começavam a vislumbrar alternativas possíveis à mineração, ${ }^{65}$ António Teles de Menezes não se demarcava da larga maioria dos agentes políticos e económicos que continuavam a acreditar na redenção da capitania através da revitalização da própria mineração. ${ }^{66}$ Mais,

Lemke, Trabalho, Familia e Mobilidade Social - notas do que os viajantes não viram em - Goiás c. 1770 - c. 1847, tese de doutoramento, Goiânia, editora da UFG, 2012, p. 69 e seguintes. Há, de certa forma, uma tentação para seguir as novas abordagens historiográficas que têm surgido em relação a Minas Gerais, à luz das quais aquela capitania teria conseguido superar a crise da mineração e encontrar alternativas economicamente viáveis a partir da $2^{\mathrm{a}}$ metade do século XVIII. Acontece que, em Minas Gerais, a cariz marcadamente urbana do seu povoamento e a sua muito maior proximidade em relação ao litoral facilitou uma reorientação da sua estrutura económica. Em Goiás, essa reorientação tornou-se muito mais problemática, por motivos diversos, embora se deva rejeitar a ideia de uma pura estagnação económica.

${ }^{62}$ Carta de António Teles de Menezes, BERTRAN, (org.), op. cit., p. 34.

${ }^{63} \mathrm{Cf}$. idem, p. 37.

${ }^{64}$ Idem, p. 38.

${ }^{65} \mathrm{O}$ governador Tristão da Cunha Meneses achava que era chegada a altura de apostar na atividade agrícola, mas diagnosticava algumas situações que perturbavam claramente o progresso da mesma em Goiás, caso dos métodos de cultivo arcaicos e a ausência do recurso a fertilizantes naturais, que fariam diminuir o corte dos matos e o recurso às queimadas. Ofício do governador de Goiás, Tristão da Cunha Meneses, ao S. E. M. U., Vila Boa, 2 de agosto de 1799, AHU, CU, Goiás, cx. 40, doc. 2475.

${ }^{66}$ Nesse particular, o discurso oficial da Coroa e dos seus representantes máximos nas capitanias (os 
ele estava convencido de que a dispersão dos mineiros por outras atividades como a agricultura ou a pecuária refletia-se negativamente na economia da capitania,

porquanto querendo acudir a tudo isso pouco tempo lhes resta para ocuparem seus escravos no verdadeiro exercício de tirar ouro, que é o mais útil e o único género exportável que sai desta Capitania, pois tudo o mais é consumível (sic) nela, por não permitirem as referidas distâncias, que daqueles géneros se possa exportar cousa alguma. ${ }^{67}$

Apontava, igualmente, o dedo a um numeroso grupo de pretos, mestiços e pardos forros, bem capacitados para o exercício da mineração e que, no seu entender, em vez disso, viviam numa "escandalosa ociosidade e vadiação" ${ }^{68}$

Também em termos sociais se foram operando alterações significativas no último quartel do século XVIII. Uma das grandes mudanças então registadas na sociedade de Goiás no período em causa foi o crescimento considerável da população livre não branca, a par com o decréscimo acentuado do número de escravos. Em 1781, a população masculina branca da capitania era de 5 350 habitantes, os negros e pardos livres ficavam-se pelos 5700 , enquanto o número de escravos era de 28486 almas (60\% da população). A capitania, no seu todo, contaria com 38261 escravos (de ambos os sexos), ao passo que a população livre era uma minoria, cerca de 20 mil pessoas, cenário que se manteve praticamente inalterável até à contagem de 1791. Todavia, em 1804, a situação era radicalmente diferente. A população livre era de 30907 habitantes dos quais apenas 6982 eram brancos. O número de escravos recuara bastante, cifrando-se nos 19889 habitantes (apenas 39\% da população). ${ }^{69}$

O que se passou no último quartel do século XVIII foi que muitos escravos conseguiram obter a sua emancipação. Fosse ou não uma consequência direta da decadência da capitania decorrente do declínio da atividade mineira ou da constatação de que, em muitos casos, a posse de escravos deixara de ser

\footnotetext{
governadores) estava em clara sintonia em relação a Minas Gerais e Goiás. No caso das Minas Gerais, Roberta Stumpf observa que a posição dos agentes governativos era de que a única solução viável para travar a decadência da capitania residia na revitalização da atividade aurífera, através do combate ao extravio/ contrabando do ouro e da descoberta de novas lavras, descartando a aposta noutras atividades que, na sua ótica, apenas serviriam para desviar mão de obra e cabedais da mineração. STUMPF, Roberta, Filhos das Minas: americanos e portugueses. Identidades Coletivas na Capitania das Minas Gerais (1763-1792). Dissertação de Mestrado, São Paulo, Universidade de São Paulo, Faculdade de História, 2001, pp. 50-97. [online, acesso a 17 de julho de 2016, URL:http://static.ow.ly/docs/RobertaStumpfDissertacao_2Xf.pdf].

${ }^{67}$ Carta de António Teles de Menezes ..., BERTRAN, op. cit., p. 39.

${ }^{68} \mathrm{Ibidem}$.

${ }^{69}$ AHU, CU, Goiás, cx. 27, doc. 1726; cx. 32, doc. 2024; cx. 36, doc. 2181; cx. 38, doc. 2380 e cx. 48, doc. 2753.
} 
lucrativa, a verdade é que "a prática da alforria, a migração e as uniões mistas gestaram uma população livre acentuadamente mestiça". ${ }^{70}$

Muitos pardos foram requisitados para os corpos militares da capitania de Goiás. O governador Luís da Cunha Meneses, demonstrando uma grande preocupação com a ordem interna, reestruturou as corporações militares existentes, apostou na integração de homens pardos, subdivididos em 8 companhias, que contabilizavam 791 homens pardos, sendo que 88 eram patentes superiores. ${ }^{71}$ Tal situação dava a esse grupo outra visibilidade e projeção social e suscitava resistências e invejas.

Também no domínio social, António de Menezes não se revelava propriamente um iluminado, antes um defensor da ordem estabelecida, muito embora as suas opiniões veiculassem um forte sentimento anticlerical. Assumindo-se como um claro defensor dos valores societários do Antigo Regime e tendo feito um percurso de ascensão social em consonância com esses mesmos valores e referências ideológicas, o capitão-mor de Vila Boa tinha dificuldade em aceitar a progressão na estrutura social de corpos e grupos que não se enquadravam nos tradicionais estatutos da pureza de sangue, ideia tão cara à sociedade do Antigo Regime. Referimo-nos aos pardos e pretos forros. A sua integração nas fileiras militares, ainda que de segunda linha, e o status que tal representava para esse grupo social emergente, não era bem visto pela elite branca local, e António de Menezes não deixava de manifestar o seu claro desagrado com a situação:

Com pardos e negros da infantaria auxiliar, não menos, em lugar de regularidade, há uma geral desordem nesta Vila e em toda parte onde eles se acham em Companhias separadas das Ordenanças, pois vendo-se a essa gente assim atendida e fardada com galões, espadas de prata e com o maior asseio que se lhes permite, não só muitos largaram o trabalho e ficaram vadios, tendo vergonha de exercer os ofícios e ocupações próprias da sua qualidade, incompatíveis com as honras de seus postos, são os que mais têm atrevido e molestado a Justiça no caso de procederem contra eles a prisões e execuções pelo que devem, chegando a tanto desaforo, que vestindo a farda, querem disputar com a Justiça os privilegiados. ${ }^{72}$

\footnotetext{
${ }^{70}$ SOARES, Márcio de Sousa, "Pretos e Pardos na Fronteira do Império, Hierarquias e mobilidade social de libertos na capitania de Goiás (século XVIII)", in 4 Seminário de Pesquisa do Instituto de Ciências da Sociedade e Desenvolvimento Regional, Rio de Janeiro, Universidade Federal Fluminense (UFF), 2010, p. 3. [online, acesso a 15 de fev. 2014, URL: http//www.uff.br/ivspers/.../ST08.3\%20Marcio\%20Sousa\%20Soares.pdf].

${ }^{71}$ Cf. SOARES, op. cit., p. 8.

${ }^{72}$ Carta de António Teles de Menezes, BERTRAN, op. cit., p. 44.
} 
Quanto à situação do clero em terras de mineração, a capitania de Goiás, pelas suas próprias características, afastada do litoral, muito extensa e pouco habitada, atraía muitos clérigos aventureiros, "em busca do ouro e das distâncias da justiça” e, frequentemente, sem "as licenças necessárias para exercer os seus ministérios". ${ }^{73}$ A cobiça, a manipulação do poder e o amancebamento eram algumas das acusações mais recorrentes que recaíam sobre os clérigos.

Segundo o ouvidor de Goiás, desde os primórdios daquelas Minas, os seus moradores viviam permanentemente sob a opressão e vexação da classe clerical. Os diversos serviços religiosos eram claramente inflacionados, facto bem revelador do desejo do lucro fácil e da ambição dos sacerdotes. Por exemplo, por uma missa cantada levava o celebrante oito oitavas de ouro, o mesmo sucedendo pela participação em qualquer procissão. Nos enterros, 0 vigário levava pela encomendação do defunto e respetivo acompanhamento 6 oitavas, ao passo que da missa que se lhe seguia cobrava 16 oitavas, enquanto os Diáconos e subdiáconos recebiam 8 oitavas cada um, o sacristão 4 oitavas, os cantores 5 oitavas, etc. No tempo das desobrigas, recebia o vigário meia pataca de cada pessoa e, se saía pelas roças a desobrigar, aí o valor já ascendia a $1 \frac{1}{2}$ oitava por cada pessoa..$^{74}$

Em relação a essa matéria, António Teles de Menezes era bastante incisivo nas críticas que fazia ao estado eclesiástico, à sua falta de ética e aos seus comportamentos desviantes, que nada dignificavam a imagem de seriedade que lhes deveria estar inerente. A sua ganância material era notória, assim como o pouco empenho nos seus afazeres espirituais e na boa condução dos rebanhos, afinal a sua principal missão:

Vão uns poucos de Pastores tosquiando os seus inumeráveis rebanhos, tirando-lhes indevidamente a própria substância de que necessitam, para se enriquecerem sem utilidade pública e com tanta avareza.

[...] E como o principal cuidado desses Vigários é adquirir e guardar as riquezas que a ninguém aproveitam, faz admirar o pouco que eles cuidam no bem das Almas, e a culpável omissão de deixarem alguns morrer muito enfermos sem os Santos Sacramentos que lhes podem, por negligência, preguiça e falta de caridade e por não terem o coadjutores precisos, que as Freguesias pelas suas dilatadas distâncias necessitam, deixando muitas vezes as próprias Igrejas para se divertirem nas fazendas e lavouras em que alguns se ocupam. ${ }^{75}$

\footnotetext{
${ }^{73}$ CASTRO, José Luiz de, Transgressão, Controle Social e Igreja Católica no Brasil Colonial: Goiás, séc. XVIII, São Paulo, Universidade Estadual Paulista, Franca, 2009, p. 101.

${ }^{74}$ Carta do Ouvidor de Goiás, AHU, CU, Goiás, CX. 3, doc. 245.

${ }^{75}$ Carta de António Teles de Menezes, BERTRAN, op. cit., pp. 39-40.
} 
No entanto, é na esfera política que António Teles de Menezes evidencia uma maior ousadia, criticando e condenando a postura de alguns dos ministros mais influentes da capitania, incluindo os próprios governadores. Sendo ele defensor dos interesses dos camaristas como legítimos representantes do poder local e dos direitos das populações, e tendo sido ele mesmo dirigente municipal, é natural que se insurgisse contra as atitudes arbitrárias assumidas por diversos governadores, que desafiavam as prerrogativas camarárias e colocavam os seus representantes numa situação de clara subalternidade. Vejamos o que ele diz sobre essa matéria:

As Câmaras a que Vossa Magestade e seus augustos predecessores sempre
atenderam e conservaram nas suas regalias e jurisdições, a desta Vila se acha
inteiramente desatendida, desapossada de sua jurisdição, e sujeita, assim como
os Ministros e os Juízes, aos despachos e Ordens dos Governadores, sem se fazer
coisa alguma que não seja a vontade e caprichos deles, a que todos se sujeitam
por necessidade, respeito e medo, e isto em tanta forma que para a Câmara
atender a algum Fiscal que deseja nomear, lhe é necessário o consentimento do
Governador, quando o Regimento lhe confere autoridade e poder de nomear
os Fiscais e os mais Oficiais da Real Casa [de Fundição]. ${ }^{76}$

António Teles de Menezes, pela sua formação académica e pela experiência acumulada no exercício dos mais variados cargos públicos, estava destinado a destacar-se no seio da comunidade local e assumir até uma postura bastante ativa nas questões da res publica. Tanto assim que, já em carta dirigida à Corte em 1777, ainda o seu processo de habilitação não havia sido confirmado, ele dirigia fortes críticas a uma das figuras mais importantes da capitania, o ouvidor e corregedor de Goiás. Considerava que o referido ministro pautava a sua conduta por parcialidades, por constantes arbitrariedades, pela desonestidade e pelo interesse pessoal, beneficiando claramente quem o apoiava ou bajulava e destratando ou mesmo perseguindo quem o não apoiasse de forma incondicional ou fosse conivente com os seus procedimentos pouco ortodoxos. E fornece-nos vários exemplos a esse respeito. ${ }^{77}$

Assim, o corregedor destratara publicamente, com injúrias e ameaças, Lourenço António Neiva, cirurgião da tropa dos Dragões e Pedestres, no dizer de Menezes, homem de boa reputação. Mandara prender Manuel Gomes Rebelo e metê-lo na enxovia por este pretender "lançar no contrato

\footnotetext{
${ }^{76}$ Ibidem, p. 42.

${ }^{77}$ Cf. carta do bacharel António Teles de Menezes, Vila Boa, 10 de agosto de 1777, AHU, CU, Goiás, cx. 29, doc. 1883.
} 
dos dízimos", e isto por ter conhecimento de que o governador de Goiás "tinha inclinação que o rematasse o socio de hum creado, como rematou". ${ }^{78}$

Em contrapartida, em relação ao tesoureiro dos ausentes da comarca de Goiás, Bento Nicolau do Livramento, que possuía inúmeros escravos, fábricas de minerar, engenhos de açúcar e muitas moradas de casas, um considerável património que foi conseguido contraindo dívidas à Fazenda Real, aos Órfãos, aos Ausentes e a muitos particulares, o corregedor, conhecedor de tudo isso, sempre se abstivera de agir contra ele, "por lhe aceitar continuados mimos, em que o dito Thisoureiro se esmerava". ${ }^{79}$

Por sua vez, nas suas constantes correições pelos diversos arraiais da capitania, o ouvidor impusera o costume de aposentadorias ${ }^{80}$ bastante dispendiosas, suportadas pelos juízes da comarca, as quais incluíam lautos jantares, presentes, etc., que o dito ouvidor retribuía, reconduzindo nos arraiais aqueles que haviam evidenciado uma maior generosidade e liberalidade nos gastos e, "pello contrario tem desatendido aos que não fazem, nem podem fazer estas grandezas, prendendo a huns, e suspendendo a outros estando com jurisdição". ${ }^{81}$

António Teles de Menezes, numa atitude desabrida e corajosa, continuava com as suas denúncias:

A seu arbítrio [do Corregedor] se despendem os rendimentos da Camara, e concelhos da comarca pagando-se as propinas tão somente aos vereadores e juízes do mayor empenho e fação do dito Ministro, fazendo aplicar as mesmas rendas em couzas estranhas, e com o que, os camaristas aprovão, por tímidos e medrosos. ${ }^{82}$

A câmara, afirmava, era manipulada pelo referido corregedor e os seus membros temiam dirigir qualquer representação ao monarca, com receio de represálias, até porque aquela autoridade beneficiava de uma grande proteção na capitania, a começar pelas cúpulas, pelo próprio governador, na medida em que, como então observava o bacharel António Teles de Menezes, "o seu mayor empenho he obsequiar, festejar, servir, e agradar aos Ex.mos Generaes, e seus creados mais estimados". ${ }^{3}$

\footnotetext{
${ }^{78} \mathrm{Cf}$. carta do bacharel, idem.

${ }^{79}$ Idem.

${ }^{80}$ Idem.

${ }^{81} \mathrm{Idem}$.

${ }^{82}$ Idem.

${ }^{83}$ Idem.
} 
Aliás, como vimos, nem sequer a conduta dos generais/governadores da capitania era poupada ao crivo crítico de António Teles de Menezes, pela ingerência em assuntos que não inteiramente da sua esfera de competência, procurando favorecer uma rede clientelar e conduzi-la para cargos importantes. Com efeito,

os officiaes das casas de fundição são inteiramente feitos e mandados nomear pellos Generaes, de sorte que na casa de Fundição desta vila estão quatro creados do General e na de São Félix hum, onde está hum fundidor mulato e suspeito, e hum escrivão de inferior qualidade [...] Com os fiscais se segue o mesmo méthodo, porque nomeando a camara presentemente a Manuel Pires Neves, juíz dos Orfãos, e o mais capacíssimo homem desta vila, se não fez caso desta acertada nomeação, por empenho de se nomear a outro inútil. ${ }^{84}$

Descontando os possíveis (ou não) exageros de António Teles de Menezes, o seu relato é precioso para mostrar como funcionavam os bastidores do poder na capitania de Goiás, como se movimentavam as redes de influências e de clientelas. Mas, para além disso, revela que o então bacharel, ao denunciar ou tecer duras críticas às autoridades que se posicionavam no topo da hierarquia local na esfera política e judicial, era dotado de uma grande frontalidade, uma frontalidade que os próprios oficiais da câmara, que tantas vezes funcionavam como um autêntico contrapoder, ${ }^{85}$ neste caso concreto receavam assumir.

\section{Considerações Finais}

A partir do que já se disse, torna-se possível reconstituir a trajetória social de António Teles de Menezes e, simultaneamente, perceber qual o seu pensamento sobre um conjunto de questões pertinentes relativas à sociedade da época, nomeadamente no espaço em que estava inserido, no Goiás colonial.

Ao reconstituir o percurso de António Teles de Menezes, podemos constatar que ele parece corporizar um conjunto de dinâmicas e valores que associamos a um bem sucedido homem do Antigo Regime no quadro do mundo português. Fora um dos beneficiados da política de mercês da Coroa e conhecera uma invejável trajetória social ascensional que o elevara à nobreza, não apenas uma auto-intitulada nobreza da terra, mas uma nobreza legalmente reconhecida pelo monarca. Assumia-se como um claro defensor dos valores sociais em vigor e da manutenção da ordenação social existente, vendo com

\footnotetext{
${ }^{84}$ Idem.

${ }^{85}$ Cf. LEMES, op. cit., pp. 71-86.
} 
clara desconfiança a emergência de novos setores sociais tradicionalmente marginalizados pelos critérios da limpeza de sangue. Mas aliava a ousadia e a lucidez suficientes para reprovar os comportamentos pouco dignos do corpo clerical em geral, ou a postura arbitrária dos próprios governadores e de outros importantes agentes políticos à escala local. Havia, pois, um misto de sintonia e de discordância/contestação perante a realidade do seu tempo, tornando-o uma personalidade bastante singular nesse Goiás colonial que se erguera em torno da economia mineradora.

Como, de forma muito oportuna, observou George Duby, um personagem singular reveste-se de uma dupla faceta:

Assume a condição comum dos seus contemporâneos, partilha os seus comportamentos, a sua mentalidade, as suas representações do mundo [...] Mas, ao mesmo tempo, pela sua personalidade singular, pelo que faz, pelo que ele próprio diz, pelo que pode haver de incongruente, de inaudito no que profere, esse homem agita, perturba o que o rodeia, engendra em torno de si ondas que se propagam pouco a pouco. ${ }^{86}$

Ora, António de Sousa Teles de Menezes enquadra-se perfeitamente nesse perfil. Bacharel em leis, seguiu as vias normais de ascensão social, enriqueceu através do comércio de grosso trato, adquiriu o hábito da Ordem de Cristo, exerceu uma diversidade de cargos na estrutura municipal considerados nobilitantes e assumiu um protagonismo político à escala local e regional, claramente demonstrado pela correspondência regular mantida com a Coroa e pela audácia na denúncia de práticas e comportamentos abusivos/arbitrários dos agentes do poder régio na capitania de Goiás, com óbvios reflexos no universo social e mental que o rodeava. Assim, António de Sousa Teles de Menezes configura uma situação de ascensão social que merece destaque no âmbito da sociedade do Antigo Regime no espaço do Brasil colonial, uma vez que, partindo de origens plebeias, explorou todas as estratégias que essa mesma sociedade, de estados e hierarquias, lhe facultava no sentido de atingir um patamar de notoriedade social.

No seu testamento, para além de todas as disposições relativas aos bens, ${ }^{87}$ manifestava o claro desejo de que o seu corpo fosse amortalhado no

\footnotetext{
${ }^{86}$ DUBYe LARDREAU, op, cit., p. 57.

${ }^{87}$ António Teles de Menezes, solteiro, constituía herdeiro dos seus bens o seu único irmão, o Doutor Bonifácio de Sousa Teles de Menezes e, sendo "falecido a seus filhos que não fossem religiosos". Cf. Justificações Ultramarinas, Brasil, maço 30, nº 6, fl. 2.
} 
António de Sousa Teles de Menezes: um caso singular de ascensão social na Capitania ...

hábito de São Francisco e no da Ordem de Cristo, uma das suas grandes conquistas e à qual ele se orgulhava de pertencer. ${ }^{88}$

Artigo recebido para publicação em 03/05/2017

Artigo aprovado para publicação em 08/06/2017

${ }^{88}$ Carta de António Teles de Menezes à Rainha, Paulo Bertran (org.), idem, 46. 